\title{
Women and National Reconciliation: Resolving the legacies of violence in post-colonial Zimbabwe.
}

\author{
Mpumelelo Moyo \\ Midlands State University, Zimbabwe \\ mpums53@gmail.com
}

\begin{abstract}
Women and their experiences are essential to the spirituality and ministry of reconciliation. The seemingly endless domination of women by men has forced them to think about alternatives and create communities of reconciliation outside of the usual paths of power and domination. Women exude the power to go beyond the hurts, the violence, rape and humiliation to build a nation and transform societies against a country's endemic culture of violence. The article explores the culture of violence in post-independent Zimbabwe and the role that women can play in creating communities of reconciliation. It is argued that in most crisis or conflict situations, women remain behind to pick up the pieces in the wake of the tornado of violence. Women can thus help communities move forward from the trap of trauma and experience the resurrection. As mothers, women offer a way of reincorporating wrongdoers and deviants back into their communities through nation building processes. This article maps a way forward for national healing and reconciliation and argues that women when empowered will play an integral part in championing the cause of good citizenry, unity and justice.
\end{abstract}

Key words: Reconciliation, women, violence, nation-building, transformation, justice

\section{Introduction}

In 2000, the UN Security Council passed Resolution 1325, which called for greater involvement of women in peace processes. The outstanding qualities of many women as well as their contribution as beacons of peace have often gone unnoticed as they are reduced to victims and survivors of violence mostly initiated by men. It is, however, the magnanimous heart of the woman that makes us realise that a future filled with peace and harmony is possible. Women have gone beyond expectations and made us realise that there is a future without revenge or fear. Abhayaratna (2006) says, as mothers, women possess an intrinsic power for peace that stems from the multiple roles they play as parents, wives, educators, role models, confidantes, friends, guardians, counsellors, coaches, storytellers, companions and soul mates. 
Many contemporary sociological studies have shown that women have unique opportunities for conflict resolution due to their unique qualities and their natural affinity towards peace and harmony. This study underscores that womanhood, being the symbol of self-sacrificing love, is an essential ingredient for reconciliation.

In her study, Nwoye (2012) has reflected on the contribution of women to peace initiatives and on the place of womanhood in Africa. In her review of six studies undertaken in six African countries - Burundi (Ntahobari \& Ndayiziga, 2003), Cameroon (Ngongo-Mbede, 2003), Central African Republic (Mathey et al, 2003), Namibia (Becker, 2003), Somalia (Mohamed, 2003) and Tanzania (Lihamba, 2003) under the framework of the United Nations Scientific and Cultural Organization (UNESCO) in 2003 to evaluate the role of women in peace resolution, she highlights the role African women have played and continue to play as ambassadors for peace.

There have also been several contributions from Okoro (2013) and Cheng (2006) all of whom write about the role of women in peace building. This study explores the contribution of Zimbabwean women in bringing about peace and reconciliation. It draws lessons from Zimbabwean traditions, which promoted the role of women as strategic partners and ambassadors for reconciliation. Through the lens of an Africana womanist approach, the article illustrates the role that women in Zimbabwe can play in creating communities of reconciliation in national healing.

Women in Zimbabwe need to play an effective role in national healing and reconciliation. The government has created structures necessary for this process to take place. However, without an effective bias at grassroots level to promote women's voices and collaboration, the process will be doomed. There is need to reconstruct the broken economy, heal the wounds of the past and restore the country's pride. There has been paid lip-service to this project for far too long even when the occasion for healing has been ripe.

\section{Cry for Reconciliation}

In Zimbabwe, reconciliation is a necessary condition for restoring the social order. It is about bringing harmony to the broken relationships through forgiveness and healing, reconstructing relationships and transforming social structures. Reconciliation is not an academic exercise; it has to be lived out. Zimbabwe is calling for reconciliation and forgiveness in its troubled context of violence, troubled ethnic and racial relationships and economic meltdown. Many in 1980 applauded Robert Mugabe on the night of his election victory for his reconciliatory speech, which reads: 
If yesterday I fought you as an enemy, today you have become a friend and ally with the same national interest, loyalty rights and duties as myself. If yesterday you hated me, today you cannot avoid the love that binds you to me and me to you. Is it not folly, therefore, that in these circumstances anybody should seek to revive the wounds and grievances of the past? The wrongs of the past must now stand forgiven and forgotten. If ever we look to the past, let us do so for the lesson the past has taught us, namely that oppression and racism are inequities that must never again find scope in our political and social system. It could never be a correct justification that because whites oppressed us yesterday when they had power, the blacks must oppress them today because they have power (Mugabe 1980).

Then, he showed the world the African weltsanschauung of Ubuntu; the virtues of trust, kindness, respect, empathy, respect for life and the dignity of life as well as common solidarity as children of God. Mugabe chose to forgive rather than seek revenge even after a protracted struggle for independence. He spoke instead about reconciliation, rehabilitation and reconstruction. In time, however, the people of Zimbabwe learnt that good intentions and good speeches were not enough and wondered if "the leadership was either naive or simply not genuine" (Kaulemu 2011, p.8), given the experience of the Gukurahundi, the Fast-track Land Reform Programme, Operation Murambatsvina and the violent election campaigns of 2008. The human effects of the violence and economic meltdown have been devastating.

The Parties to the Government of National Unity (GNU) also felt the need to focus on National Healing. The GNU set up an initiative on National Healing and Reconciliation, appointing three ministers responsible for "Healing and Reconciliation" and an Organ for National Healing and Integration was also established. Its impact or lack of, would have to be understood within a wider Zimbabwean context of thirst for healing and reconciliation. After the GNU, Vice President Phelekezela Mphoko was tasked with the National Healing and Reconciliation portfolio. There was a realization by government of the need to address the painful memories of the past. Further, the government realised a need to build relationships at both grassroots and national levels hence appeared to create a conducive environment for healing and reconciliation to take place.

Reconciliation has social and spiritual dimensions. The spiritual dimension deals with forgiveness and healing. The social dimension is about providing structures and processes for reconciliation, such as the Truth and Reconciliation Commissions. According to Schreiter; 
The state can set up commissions to examine the wrongdoing of the past, but it cannot legislate the healing of memories. The state can offer amnesty or mete out punishment to wrongdoers, but it cannot guarantee forgiveness. Social reconciliation sets up conditions more likely, but those conditions cannot of themselves effect it. That is why secular NGOs (nongovernmental organisations) turn to their religious counterparts and ask for help with the necessary spiritual dimension (Schreiter, 1999 p.4).

Women's experiences and the rich African cultural heritage can help bring about healing and reconciliation. Reconciliation is never in a vacuum as conditions under which reconciliation can take place need effort. The role of women as ambassadors of reconciliation cannot be ignored in laying the groundwork for true peace and harmony. Because reconciliation means a change of heart, transformation of attitude and character. Reconciliation for Zimbabwe would have to include public truth telling, official acknowledgement and acts of forgiveness. It is a community task that cannot be left to individuals.

\section{Zimbabwe's story and the need for healing.}

The message and need for national reconciliation and forgiveness was raised by the Zimbabwean Churches in their 2006 document "The Zimbabwe we want: towards a national vision for Zimbabwe". The churches stressed the cry for reconciliation by Zimbabweans and acknowledged the historical developments that gave rise to this process. Churches demanded that a national reconciliation process be initiated if the nation was to share the same vision for Zimbabwe.

The injustices and violence of the past have deeply impacted on the people and left them traumatised. These experiences of powerlessness needed to be interpreted, explained and given some meaning. In Zimbabwe, violence has taken different forms being physical, psychological, institutional and social (CIM, 2007 p.176). Zimbabweans have not seriously acknowledged or reflected on the culture of violence, which has permeated their national psyche (CIM, p.179). Although writings by academics on violence have begun to appear (Kaulemu 2011; Sachikonye, 2011), Zimbabwe needs to address its painful heritage in order to forge ahead.

The experience and violence of the Gukurahundi era left a deep trauma. It shall remain a festering wound until it is squarely faced. There is need to bring to the surface the hidden tension where it can be seen and dealt with (ZCBC, ZCC, EFZ and HCD, A Call to Conscience, 2005 CiM, 2007 p.10). The horrible events of the period are recorded in Breaking the Silence, (CCJP/LRF, 1997, see also Ranger et al. 2000; Werbner, 1995).) An extract will suffice as a foretaste of the human tragedy that led to the estimated death of 20000 people; 
The deployment of the Fifth Brigade introduced terror and hardship on a scale civilians had known neither in the mounting insecurity of the 1980, nor in the height of the guerrilla war. The Fifth Brigade's exercise of violence was concentrated within a relatively short period - just under a year - and was perceived as unique. It overtly justified its violence in political and tribal terms. It not only systematically attacked ZAPU and other community leaders but it also attacked civilians at large, civil servants, and even ZNA units and police. The death toll was high. (Sachikonye, 2011 p.15, CCJP/LRF, 1997 p.217).

The killings, disappearances and displacements that were perpetrated under the Gukurahundi have to date not been formally acknowledged by the state (Sachikonye 2011 p.17), with the single exception from Minister Moven Mahachi who said,

... events during that period are regretted and should not be repeated by anybody, any group or people or any institution in this country (The Sunday Mail 6 September 1992; CCJP, 1997 p.5).

The then state President, Robert Mugabe, dismissed Gukurahundi as having been "a moment of madness". However, it is a 'moment' that needs to be formally acknowledged if the victims are to access justice and restitution and healing.

The culture of politically motivated violence between ZAPU and ZANU has its deep roots in Zimbabwean politics from the 1960s. Political violence in Zimbabwe has been orchestrated by certain individuals with specific aims to gain leverage, political and economic power. According to Sachikonye (2011 p.8), "political violence is a strategy with a specific aim," which is often well planned. Intra-party or inter-party violence has been used to intimidate and harass rivals out of the competition, or as acts of retribution.

Political violence in Zimbabwe has many levels, from basic or mundane forms of violence to sophisticated violence (Sachikonye, 2011 p.17). The history of election related violence can be traced back to the 1980 elections, increasing in 2000, 2002, 2005, and 2008 becoming the most lethal year in the country's election history. This became part of a wider pattern of state violence (Ganiel \& Tarusarira, 2012 p.58). The scope and intensity of violence and terror witnessed in the presidential run-off campaign in April-June 2008 was unprecedented. Cases of violence during Operation Makavhotera Papi are well documented (CCJPZ 2009; HRW 2008; ZPP 2008; CSU 2010). The brutal torture and violence was punishment for voting for MDC (Movement for Democratic Change) in 2008. The perpetrators used in these attacks were often non locals in a given area who used information provided by locals of a village or place. 
CCJPZ (2009) reported that perpetrators moved in groups of up to 30 and established 'distinguishable bases' supplied from confiscated foodstuffs and other necessities. Further, it was reported that the overwhelming numbers of perpetrators made it difficult for individual victims to defend themselves. The tools used varied from logs, sjamboks, machetes, steel rods, knobkerries to knives and chains. However, there were cases where tools and equipment associated with security agencies like the police (batons and guns) were used in the perpetration of the violence, suggesting the direct involvement of state security agents or deliberate issuance of such tools to party militia (CCJPZ, 2009 p.43).

Those who fell victim could not get assistance from police or medical treatment at clinics or hospitals, compounded by prohibition of movement by humanitarian agencies and NGOs (Sachikonye, 2011 p.51).

\begin{abstract}
Zimbabweans have endured hatred, political violence, abuse, disappearances, displacements and murders by individuals bent on gaining political mileage or trying to settle personal vendettas. There are serious issues to do with politically motivated violence that the nation needs to look into in order for healing and reconciliation to be achieved. This has left our political space polarized and in need of healing and forgiveness.
\end{abstract}

The fast-track land reform programme of 2000 also left a trail of violence. The violence that accompanied the 'land invasions' or 'jambanja' (chaos) resulted in the emergence of a culture of racial hatred and alienation. The farm invasions were accompanied by a wave of anti-white rhetoric and violence, which security forces largely ignored (Ganiel \& Tarusarira, 2012 p.58). Sachikonye (2011 p.17) attests that the violence had a dual role: "it was deployed to seize land from 4,500 farmers and to destroy the political base for MDC amongst farm-workers." The land reform process involved considerable violence, sanctioned by the state. Therefore, for reconciliation to take against the realities reported above there must be a consensus on resolving the land issue through mechanisms that can support equitable distribution of land for all citizens.

In 2005, the government initiated Operation Murambatsvina (Operation Remove the trash or Restore Order). The programme destroyed people's homes and livelihoods. Many people were left destitute. The human effects were devastating as detailed in the United Nations (UN) (2005) report on the impact of Operation Murambatsvina (United Nations, 2005; Vambe ed., 2008). According to Sachikonye (2011), the real motivation of Operation Murambatsvina was political retribution in the aftermath of the 2005 elections (Sachikonye, 2011 p.27) with the opposition MDC party having garnered more votes in urban centres. The social and economic impact of the programme was massive, leading many to think of it as a 'tsunami.' The methods and 
timing of this operation left many scars of bitterness and a sense of betrayal. The destruction of people's homes and their businesses without alternative arrangements prior to the 'tsunami', caused great suffering. Many victims of Murambatsvina are still without housing, jobs and social services. The suffering continues unabated. Kaulem (2011 p.ix) summarises Operation Murambatsiva era it as follows;

Zimbabweans live on the edge, always living in fear, the fear being found without the correct party card, fear of making the correct slogan, fear of saying politically wrong things; fear of being seen in the company of wrong people, the fear of being taken away; the fear of losing a job; and many others.

\section{Reconciliation and National Healing}

Reconciliation is not an event but a process built on trust. The process renders opportunities for a fractured community to do an examination of conscience. It allows the community to look at itself honestly and acknowledge the past, by both victims and perpetrators, while challenging both to look for a high good. According to "the Zimbabwe we want document":

Reconciliation implies that the parties concerned both move ritually and physically from previous entrenched positions of advantage, comfort and defence to positions of discomfort, vulnerability and compromise (ZCBC/ZCC/AFZ, 2005).

There are no victors in the process of reconciliation, both parties come out radically transformed by the experience of healing and forgiveness. It is only after this process that the lost harmony is restored. Reconciliation goes together with a broader renewal of socio-economic and political structures. It focuses on reforming the conscience and attitude of the victims.

There are yet to be pragmatic pointers to Zimbabwe as having experienced genuine reconciliation even after the famous Robert Mugabe 1980 "reconciliation speech." Kaulemu (2011 p.2) asks a very pertinent question: "How could the virtues of brotherhood, comradeship develop from the hate, wounds and grievances of the past?" There have not been conducive conditions to allow the reconciliation process to take place. The blanket amnesty was unprecedented approached on the assumption that people would forgive and forget. At independence, the whites continued to enjoy the benefits of past atrocities committed on blacks without remorse or shame. It was important for Zimbabweans at independence to set in motion a process of healing of memories and broken relationships. There was a need to nationally ritualize or symbolize this process using traditional methods of dealing with conflict. 
In African culture, deviants had to show remorse and give restitution for any wrongful acts they may have committed. For example, a man who wronged his wife had to invite the woman's aunt to come and reconcile them. The wrongdoer would be asked to perform a formal act called kubatamakuku/ikuvumaindaba (find something or give a token, say a chicken) which he would present to the aunt. In the presence of gathered relatives and elders, the aunt would address all present in these or similar words after the necessary acknowledgements of those present, "Your son is asking for forgiveness from his wife. Receive this token as a sign of being sorry for what he has done to you." The aunt would give the chicken to the wife who would accept it gladly. After that, the aunt would counsel the couple to live in love and uphold the virtues of marriage. The elderly members of the family also took turns to advise the couple. Finally, they ended up sharing a meal together as a sign of reconciliation (Zvarevashe, 2005 p.23). We thus learn a lot from embracing indigenous knowledge systems of resolving conflict.

Zimbabwe hungers for reconciliation. Past hurts, intimidation, fear and violence need to be pragmatically addressed if sustainable development is to be achieved. In order to achieve this, there is need by the government and all stakeholders to seriously undertake processes of bringing harmony and peace to the people of Zimbabwe. The government needs to take seriously its constitutional mandate and operationalise the National Peace and Reconciliation Commission (NPRC), which is a constitutional provision under Chapter 12(6) of the country's constitution.

The government needs to formally acknowledge its past sins and take a bold stand. There is also need for reparation and justice. Further, monuments and rituals need to be erected to remind victims and perpetrators of past mistakes so that the same should never be repeated or allowed to happen such as has been the case with the Jewish holocaust memorials or monuments, and remembrance days. Victims of wrong doing, according to the Catholic Commission for Justice and Peace Report (CCJP) (1997 p.5) "Do not want a witch hunt, but just a chance to be heard."

\section{Women in Zimbabwe}

Zimbabwe has accomplished a lot in improving the status of women and considerable effort has been made towards attaining women's empowerment. Women in Zimbabwe play a critical role in sustainable development. The participation of women in the liberation struggle and on the battlefield transformed the image of the Zimbabwean woman. Women proved to be just as able and dedicated as men. Women in Zimbabwe are excelling in all spheres of life. The country has had a woman Vice President (2004-2014) (Joyce Mujuru), President of the Senate (Edna Madzongwe), besides several women Ministers. Although there was discrimination 
and oppression of women in the past, the post-colonial government introduced legal reforms concerning the status of women. These include the Legal Age of Majority Act, the Matrimonial Causes Act, the Maintenance Amendment Act and the Equal Pay Regulations Act. The most far reaching was the Legal of Age Majority Act of 1982 which opened the way for other reforms to take place. The Act established the principle of equality between men and women.

Women in Zimbabwe have suffered from discrimination and oppression. Whether it be in family, social and political life, in sexual relations, education and business. The Zimbabwean woman has come a long way and has fought hard for her right to sit at the table. Today, the Zimbabwean woman is not a push over as her rights and position is defended by the constitution. Most of all, the Zimbabwean woman is "Amai /Umama" (mother) a word that means more than its European equivalence.

In Zimbabwe, every woman is fondly and respectfully called "Amai/Umama". Africans have no other way of crying and expressing pain, shock other than to exclaim "maiwe!/maibabo". Unfortunately, this exclamation has no English equivalence in meaning or depth and may be a bit close in equivalence to the Italian exclamation "mama mia". Maiwe/maibabo is a word that expresses deep shock, pain and anguish used by men and women to call on their mothers for comfort and solace. In Shona, there is an expression that says "kusina mai hakuendwi" (you should never go where you mother is not). This literary means that a child is only safe in the presence of its mother.

Women played many roles in traditional African society as mothers, educators, advisors, providers, caregivers, (svikiro) spirit mediums, n'anga/inyanga (traditional healers) and in some instances as heads of households or chiefs. In marriage a woman acquired status through the payment of roora/amalobolo (bride-price), not the one of being a wife but of being a provider for her own family (Bourdillon, 1987 pp.50-57). Women are viewed in many traditional African societies as a source of life and medium of communication (Musopole, 1997). A mother creates a close bond within her family. She is the primary educator to her children and boys are weaned off at the onset of puberty to be taught manly things such as hunting by their fathers. Through a mother's touch, traditionally, the boy was taught to be responsible. However, the education of girls was delicate and more formal so that she would be the pride of her family and husband's family. In death a mother's spirit was regarded as friendly and protective (Musopole, 1997 p.32).

The authority of the woman was through her power of influence as husbands would defer their decisions until they had consulted the wife. Women, according to Bourdillon (1987 p.53), had more influence in the homestead than they or their menfolk cared to admit. However, there have always been a few women in less 
subtle authority in traditional society as chiefs, head women or as spirit mediums. An example is Mbuya Nehanda who has become a national icon in Zimbabwe. The area of traditional medicinal herbs and healing was often the preserve of women, who also acted as spirit mediums. Women were viewed as mediums of communication between humans and God. The woman had the responsibility of caring for the sick as well as custody of the corpse until its burial. Further, women had a duty to support and provide for their families, often through agriculture and other commercial activities.

Women in both traditional and contemporary society defy patriarchy and challenge gender biases using various means. Even though women suffer from lack of cultural, political and economic power, they continue to work in creative ways to subvert patriarchy. Therefore, the empowerment of women should be an ongoing process. In so far as women are disempowered, men too are disempowered (CiM, 2007). The contribution of women is not insignificant or negligible. Despite the gains, effort is expected in the promotion of gender equality as well as fight gender based violence and all forms of sexual abuse. If given the necessary support, women have a critical role to play as they can tower over men in mental and material achievements (Nwoye, 2012). Thus women have the potential to transform any given society. Therefore, they also have an important and essential role to play in the national healing process and sustainable development.

\section{Women and Reconciliation}

Women, their experiences and stories have a positive contribution to peace building and healing of memories. As agents of healing women can help us build bridges of reconciliation. The endless school of domination by men has taught women to look for alternatives, like positive thinking in a time of desolation. By thinking outside of the box, women can help us imagine alternative experiences, from those of being imprisoned in a traumatic experience. Men can learn a lot from listening to women, respecting their magnanimity and willingness to forgive. They can create bonds of solidarity with those who have been disenfranchised and callously trodden underfoot as survivors of violence. Women are an embodiment of reconciliation as illustrated in these two stories from the Truth and Reconciliation Commission (TRC).

One woman who came forward told the story of having been forced to watch her son's execution. She was not allowed to say good-bye to him, nor was she allowed to claim his body. All she wanted to know is where he had been buried. 
Another woman came forward to the Truth and Reconciliation Commission (TRC) in South Africa to describe how her son had been taken away from her home, tortured, and killed; she told the Commission that his body had been returned to her. When asked by the presiding officer what she wanted from the new government, she paused a moment and then said, "I want the government to buy a tombstone for my son." She did not ask for justice for her son, only a tombstone. Reconciliation had touched her heart, and she did not seek revenge. She only wanted acknowledgement on the part of the new government of what the apartheid government had done (Schreiter, 1999 pp.26-27).

There are many stories of women with great hearts who were willing to forgive and seek an alternative to harbouring the trauma of the past and end conflict. For example, in Liberia and in Sierra Leone, mothers got together and went to the bush to persuade child soldiers to give up arms. In Somalia it was the women who brought the clan leaders to the negotiating table for the first time. The Mano River Women's Peace Network comprising of women from Guinea, Liberia and Siera Leone rallied together to call for disarmament and paved the way for peaceful negotiations. In India and Pakistan women have played a significant part in bridging the gap between the two countries by organizing rallies to unite citizens of both countries. In Northern Ireland women served as mediators between Catholic-Protestant conflict.

The women of the Wall of Peace in Croatia would not allow the troops to rape Serbian women in revenge to what had been done to Croatian women by forming a Wall of Peace. We are also reminded of the women of the comedores populares (popular kitchens) in Lima who presented a different image of women by feeding children in a country that recruited women to stage executions and the Mothers of the Plaza de Mayo who gathered in the heart of Buenos Aires in 1977 to protest against the disappearance of their loved ones. Closer to home, the President of the Chiefs Council Fortune Charumbira thanked Sekai Holland for her role in peace building. "You (Holland) are unique. Everyone knows that you were once beaten up by the police and hospitalised. How can you forget all that and start to preach unity is everyone's question?" (The NewsDay, 24 March 2015).

These narratives illustrate the relentless role women play in ending violence and bringing about reconciliation. They too are victims due to their own involvement or as punishment to a spouse's involvement in politics. Men are most frequently the source of violence and women are often left to repair the damage. Women in Zimbabwe can teach us not to seek revenge but to find alternatives. 


\section{Women's Contribution to Reconciliation}

In Shona, there is an expression that says Musha mukadzi, meaning it is the woman who makes the home. The dignity of a home and the atmosphere that it exudes are often reflective of the quality of the wife and mother. Respect and love are learnt from the mother. It is not a fallacy, that Archbishop Desmond Mpilo Tutu would dedicate his book No Future Without Forgiveness (1999), "To the women and the 'little people' of South Africa". It is the women as the little people who like a mustard seed can open our hearts to forgive and transform the hurts of the past into something positive and beautiful.

In August 1975, three children, who were siblings, were tragically killed in Northern Ireland amidst the Catholic-Protestant conflict. In protest against the senseless killing, Betty Williams and Mairead Corrigan, a housewife and an aunt of the victims respectively, two women from different backgrounds, risked their lives in war torn Ireland. They united Catholics and Protestants by leading nonviolent demonstrations protesting against the bloodshed. For their courage and work they were jointly awarded the 1976 Nobel Peace Prize (Cheng 2008 p.4).

There are several ways in which women can contribute positively and effectively to national healing in Zimbabwe. Women through civic and church organizations, women's power and collective purpose can force social and political reforms that make healing of memories possible as seen in the actions of Williams and Corrigan and many others like them. The maternal instinct in all women, has power to bring hope and goodness where we least expect it. Women's tenacity in the face of danger and intimidation, can give us the courage and help us navigate through the obstacles of life. There are many unsung women heroes who have fought hard for women's rights, advocated against gender based violence and vouched for social and political reforms. Some have been arrested, physically assaulted, tortured and sexually abused.

What one finds amazing is that many of them are not bitter. They remain committed to change in non-violent ways, such as Sekai Holland, Jenni Williams, Magodonga Mahlangu, Jestina Mukoko, Beatrice Mutetwa and many others. It is through the efforts of these individual women and groups such as Women's Coalition for Zimbabwe (WCoZ), Women of Zimbabwe Arise (WOZA), Zimbabwe Women Lawyers for Human Rights (ZWLR), Women Action Group (WAG), Grassroots Women's Network (GWN), Musasa Project, including Faith Based Organisations such as Young Women's Christian Association (YWCA), Ruwadzano RwaMadzimai, Mbuya Anna, Chita chaMaria Musande that the cause for national healing can be addressed. 
Women as primary educators can bring forth peace initiatives at home, in the community and nation. The United Nations theme for International Women's Day is "Equality for Women is Progress for all," this theme completes the adage "educate a girl and you educate the world.' Women are agents of change, the attitudes of women are more influential in bringing about social change, for example in medical practices and agriculture. This is why it is important to engage women at all levels of the national reconciliation agenda.

According to Shreiter (1999 p.15), "God begins the process of human reconciliation with the victim. It is through the victims that the wrongdoers are called to repentance and forgiveness. Seen from this perspective, repentance and forgiveness are not the preconditions for reconciliation, are the consequences of it." The moment of reconciliation comes as a surprise and touches both the perpetrator and victim. However, we need not to rely only on God touching the individual soul. We need to create conditions and structures that make reconciliation possible such as the National Peace and Reconciliation Commission (NPRC), Organ For National Healing, Reconciliation and Integration which can be essential in operationalising the process of national reconciliation, through mass media campaigns, through televisions, radio and print media stressing the value of the process, aligning the laws to allow for reparation or amnesty, memorisation and ritualization need to be effected as key to the process.

These initiatives can only be possible if government comes on board, or is forced by advocacy groups to take national healing seriously. Women can be influential in these processes, since they themselves have been victims. Women, unlike men, can transcend the trauma of abuse and marginalisation and still find positive ways of dealing with the hurts of the past. One needs to merely listen to the many songs dedicated to mothers to understand their courage and resilience in the face of obstacles.

In traditional African societies, women would go to all lengths and use creative stratagems in conflict resolution (Cheng, 2006). For instance, in the case of ngozi (avenging spirit of a wrongly killed person), maidens were offered in marriage to the family of the murdered person to appease his/her spirit. The marriage constituted an inviolable alliance between the warring parties, thus creating a family bond (Nwoye, 2012). Among the Korekore-Nyombwe of Zimbabwe; 
The girl who was given to the victim's family was expected to bear a child to replace or restore the deceased victim. Once the girl who is given as wife to the victim's family has conceived and given birth, she returns to her relatives unless the man who fathers the child decides to go and pay bride price to the family of the offender in which case they will be marriage formalities. The man cannot continue to have another child with the woman until he pays bride price as this will upset ancestors and thereby invite ngozi to the family (Mangena, 2012 p.84).

This process brings the two families (the family of the victim and that of the perpetrators) together. According to Mangena (2012 p.78), the process ensures renewal of life and restoration of strained relationships.

Among the Ndebele people of South-western Zimbabwe, the community would call on the Ndlovukazi (the King's mother) to intervene in times of social conflict. This role was also played by the grandmothers, aunts and wives who would mediate for conflict resolution. A woman's subtle influence and mediation would lead to peace. Zimbabwean women have a mitigating influence if only they can realise their power and potential for bringing peace and harmony. Women can help us transcend our desire for revenge, pettiness and seek genuine reconciliation. And through some of the few narratives above, we note that women can deliver, if they are empowered to facilitate healing and reconciliation programmes.

\section{Conclusion}

There is evidence to suggest that the Zimbabwean nation is hurting. There can be no sustainable development without the country having to face its past as there have been many bloody conflicts, which have bred tensions and mistrust. Violence, of all forms, has been seen to be destructive. Nkomo (1984 p.168) wrote:

The worst thing about the war was the callousness it bred. It is true, and I regret it, the atrocities were committed by people on our side, by Zipra fighters as well as by Zanla men. Some of those killed were isolated white farmers and their families who happened to be in the way. Some were African chiefs who may have collaborated with the Smith regime, but who had little alternative if their own families and their peoples were to survive. It was not our policy to kill such people. But armed men, alone in small groups, may come to disregard the importance of human life. It was necessary to fight guerrilla war, and in such a war terrible things are bound to happen.

It is this 'callousness' that has bred violence and economic meltdown, mistrust and greed. The government needs to operationalise the National Healing and 
Reconciliation Commission (NHRC) for an effective implementation of its constitutional mandate if the government is serious about reconciliation. It would need to empower organizations such as Organ for National Healing, Church and Civil Society Forum, other organisations and individuals with a common purpose.

Women are an essential constituent of this process as strategic partners. Women as we have discovered are ambassadors per excellence and need to be involved at all levels. Women's contribution to creating communities of reconciliation and contributing to national healing is phenomenal. Without the involvement of women at all levels, the process of national healing will be doomed. Women exude hope that enemies might be again be friends, that perpetrators will recover their lost humanity, as witnessed in the narratives of women in the Truth and Reconciliation Commission, Wall of Peace and many others.

African culture teaches us to condemn and punish the crime, but most importantly to rehabilitate the offender and thus create harmony and restore the brokenness of our society. This is only possible through a mother's sacrifice and love for her family, because she is a survivor of discrimination and oppression, and has found alternatives to the culture of violence, intimidation and fear. She can see the big picture, better than her men folk entrenched in violence. Gandhi best describes the role of women when he says;

If by strength is meant moral power, the woman is immeasurably man's superior. Has she not greater intuition, is she not more self-sacrificing, has she not greater powers of endurance, has she not greater courage? Without her man could not be. If nonviolence is the law of our being, the future is with woman (Young India, October 4, 1930).

Their passion, determination and resilience inspire the nation. They can never be true reconciliation without the positive contribution of women.

\section{REFERENCES}

Becker, H. 2003. Women, Politics and Peace in Northern Namibia. In UNESCO, Women and Peace in Africa (pp. 47-73). Paris: UNESCO.

Bourdillon, M. 1987. The Shona Peoples. Gweru: Mambo Press.

Bronkhorst, D.1995. Truth and Reconciliation: Obstacles and Opportunities for Human Rights. Amsterdam: Amnesty International. 
CCJP/LRF (Catholic Commission for Justice and Peace and Legal Resources Foundation). 1997. Breaking the Silence, Building True Peace: A Report on the Disturbances in Matabeleland and Midlands 1980 to 1988. Harare: CCJP.

Cheng, Q. G. 2006. Ordinary Women, Extraordinary Qualities: Women as Role Models in Peace Efforts: Singapore: University Women Association of Singapore. http://www.uwas.org/uwasArchive/Conferences/Paper_ordinarywome_Xordinary qualities.pdf. Accessed 15 August 2015

Chirenge, G. 2012. Peace Building: Any Hope for Young Women as Strategic Partners? In BUWA A Journal of African Women's Experience (pp68-73) Johannesburg: OSISA

Church and Civil Society Forum (CCSF). 2010. Towards Development of a National Framework for National Healing, Integration and Reconciliation in Zimbabwe Harare: CCSF November 2009-2010.

Churches in Manicaland. 2007. The Truth Will Make You Free: A Compendium of Christian Social Teaching.

Ganiel, G. and Tarusarira, J. 2012. Reconciliation and Reconstruction among Churches and Faith-Based Organisations in Zimbabwe

Kaulemu, D. 2011. Ending Violence in Zimbabwe. Harare: Konrad Adenauer Stiftung (AFCSAT).

Lihamba, A. 2003. Women's Peace Building and Conflict Resolution Skills, Morogoro Region, Tanzania. In UNESCO, Women and Peace in Africa (pp.111-131). Paris: UNSCO Workshops.

Mangena, F. 2012. On Ubuntu and Retributive Punishment in Korekore-Nyombwe Culture: Emerging Ethical Perspectives. Harare: Best Practices Books

Mathey, M. J., Dejan, T., Deballe, M., Sopio, R., Koulaninga, A., \& Moga, J. 2003. The Role Played by Women of the Central African Republic in the Prevention and Resolutions of Conflicts. In UNESCO, Women and Peace in Africa (pp. 35-46). Paris: UNESCO Workshop.

Mohamed, A.M. 2003. The Role of Somali Women in the Search for Peace. In UNESCO, War and Peace in Africa Paris: UNESCO Workshops. (pp. 75-110).

Mukonyora, I. 1999. Women and Ecology in Shona Religion. Harare: University of Zimbabwe. 
Women and National Reconciliation: Resolving the legacies of ...

Ngongo-Mbede, V. 2003. The Traditional Mediation of Conflicts by Women in Cameroon. In UNESCO, Women and Peac e in Africa (pp.27-34). Paris: UNESCO Workshops.

Nkomo, J. 1984. The Story of My Life. London: Methuen.

Ntahobari, J., \& Ndayiziga, B. 2003. The Role of Burundian Women in the Peaceful Settlement of Conflicts. In UNESCO, Women and Peace in Africa (pp.11-26), Paris: UNESCO Workshops.

Nwoye, M. A. C. 2012. Role of Women in Peace Building and Conflict Resolution In African Traditional Societies: A Selective Review. Nairobi: Kenyatta University. http://www.afrikaworld.net/afrel/chinwenwoye.htm Accessed 15 August 2015.

Oduyoye, M. A. \& Kanyoro, M. R. A. (eds.) 1997. The Will To Arise: Women Tradition and the Church in Africa. New York: Orbis Books.

Okoro, K. N. 2013. Women and Peace Initiative in Igbo Traditional Society: A Viable Option for Peace Building in Modern Africa. Humanities and Social Science, Vol 1, No1, 58-69

Sachikonye, L. 2011. When a State turns on its Citizens. Harare: Jacana.

Schmidt, H. 1997. Healing the Wounds of War: Memories of Violence and the Making of History in Zimbabwe's Most Recent Past. Journal of Southern African Studies, Vol 21, No 2, 301-310.

Schreiter, J.R. 1998. Reconciliation: Mission and Ministry in a Changing Social Order. New York: Orbis Books.

Tarimo, A. and Manwelo, P. 2007. African Peace Keeping and Governance. Nairobi: Acton Publishers.

Tutu, D. 1999. No Future Without Forgiveness. New York: Doubleday

UNESCO, 2003. Women and Peace in Africa: Case Studies on Traditional Conflict Resolution Practices. Paris: UNESCO

United Nations, 2005. 'Report of the Fact- Finding Mission to Zimbabwe to Assess the Scope and Impact of Operation Murambatsvina by the UN Special Envoy on Human Settlements Issues in Zimbabwe Mrs Anna KajumuloTibaijuka' (New York: United Nations 
Vambe, M. (ed.) 2008. The Hidden Dimensions of Operation Murambatsvina in Zimbabwe. Harare: Weaver Press.

Walsh, T. G. \& Kaufmann, F. (eds.) 1999. Religion and Social Transformation in Southern Africa. St Paul: Paragon House.

ZCBC (Zimbabwe Catholic Bishops' Conference), EFZ (Evangelical Fellowship of Zimbabwe) and Zimbabwe Council of Churches (ZCC) 2006. A call to Conscience, April 2005.

ZCBC (Zimbabwe Catholic Bishops' Conference), EFZ (Evangelical Fellowship of Zimbabwe) and Zimbabwe Council of Churches (ZCC). 2006. The Zimbabwe We Want: Towards a National Vision for Zimbabwe: A Discussion Document. 15 September2006. Harare: ZCBC

ZCBC (Zimbabwe Catholic Bishops' Conference). 2007. God Hears the Cry of the Oppressed: Pastoral Letter on Current Crisis in Zimbabwe, Thursday, 5 April 2007. $Z C B C$

http://article.sciencepublishinggroup.com/pdf/10.11648.j.hss.20130101.17.pdf Accessed 15 August 2015. 